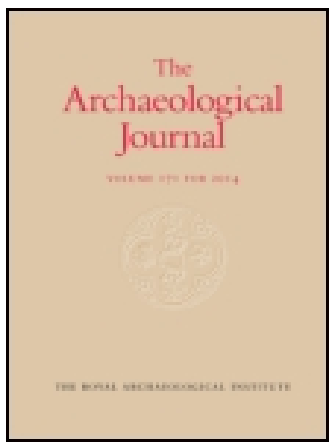

Archaeological Journal

\title{
On the Chap-Books in the Bibliotheca Jacksoniana in Tullie House, Carlisle
}

\section{Chancellor Ferguson F.S.A.}

To cite this article: Chancellor Ferguson F.S.A. (1895) On the Chap-Books in the Bibliotheca Jacksoniana in Tullie House, Carlisle, Archaeological Journal, 52:1, 292-335, DOI: 10.1080/00665983.1895.10852676

To link to this article: http://dx.doi.org/10.1080/00665983.1895.10852676

央 Published online: 16 Jul 2014.

Submit your article to this journal $₫$

Џll Article views: 6

Q View related articles $๘$ 
ON THE CHAP-BOOKS IN THE BIBLIOTHECA JACKSONIANA IN TULLIE HOUSE, CARLISLE.

By Chaycellor ferguson, F.S.A.

Halliwell, in his valuable Dictionary of Archaic and Provincial Words, defines a Chap-book as "A little book printed for the purpose of being sold to hawkers". Slater, in his Library Manual, says it is "A small book or pamphlet carried about for sale by hawkers ". and he instances Last dying speeches and confessions as familiar examples of chap-books. But it must not be supposed that chap-books are nothing but "dying speeches and confessions", or that dying speeches and confessions form a large class of chap-books; Mr. R. H. Cunningham, in his book called Amusing Prose Chap-books, p. $7,{ }^{2}$ divides the Litteratura Vulyi, or chap-books, into the following classes :-(1) Historical, (2) Biographical, (3) Religious, (4) Romantic, (5) Poetical, (6) Humorous, (7) Fabulous, (8) Supernatural, (9) Diabolical, (10) Legendary, (11) Superstitious, (12) Criminal, (13) Jest-books, etc. Of these classes Mr. Ashton ${ }^{3}$ considers the strictly religious to be the smallest in number, an opinion in which the present writer is hardly disposed to agree. Much, however, depends upon what Mr. Ashton means by "strictly religious".

Judging from the number of chap-books devoted thereto, the supernatural and the superstitious must have had great charms for readers; while old romances, handed down from days anterior to printing, had great popularity, but the poetical and the humorous had the greatest predominance. Collections of ballads or songs form an enormous class under the name of "Garlands", having generally on their title-page the words

\section{A GARLAND}

of

NEW SONGS.

1 Read at the Monthly Meeting of the Irstitute May 1st, 1895.

- London: Hamilton, Adams \& Co. Glasgow : 'Thomas D. Morrison, 1889.
3 Chap-books of the Fighteenth Century, by John Ashton. Chatto and Windus, London, 1882. 
To face page 292.

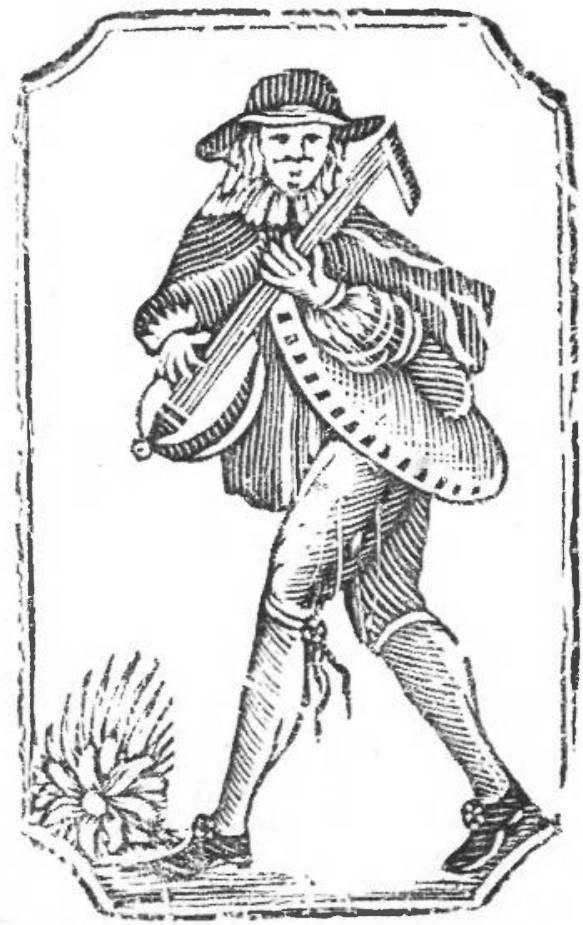

CHAP-BOOK BLOCK, FROM SOULBY'S OFFICR, PENRTH. 
These "Garlands" may sometimes be dated by the inclusion therein of a song by some known writer, Dibdin, Burns, Campbeli, or the local Cumberland writers, Anderson, Evan Clark, and Relph, or by a reference to some public event, such as a naval or military victory, but the imprint of a chap-book, as a rule, only says " Printed in this present year." Taies of adventure are not uncommonly the subjects of chap-books, and in a recently published list of books upon Morocco, issued by the Geographical Society it is stated that,

Up to 1820 most of our information about Morocco was derived from Christian captives, who had been taken and held in slavery of the most grinding description : many of them are of great value and extreme pathos, mostly hawked as chap-books for the benefit of the returned slave.

A writer in an American publication says : ${ }^{1}$

Tle chap-book per se may be regarded as a later seventeenth century product. It first made its appearance as a distinct branch of a literary tree soon after the Commonwealth period, when those numerous obscure presses that had been busily disgorging floods of broadsides and pamphlets pro and con the great questions of the day, found, when these questions were settled, no other usefulness left them than to supply with lighter material that appetite for reading matter which they had excited in the masses. All manner of old and popular stories, tales, quips, jests, and facetiæ (oftentimes totally unfit for nineteenth century reading) were collected and crystallised into a cheap folk-literature, fit for the fireside and the rush-light. For disseminating this mass of popular publications no one was so well fitted as the chapman.

So much was this the case, that many of the early chapbooks have as their imprint, "Printed for the Company of Flying Stationers", also "Walking Stationers". The chap-book is geverally found printed upon a sheet of coarse grey paper, folded so as to make a little stitched book, generally of eight páges, but some extended to twenty-four pages; these were known in the trade as "twenty-fours", and gradually superseded the eight page books. Chap-books were illustrated with rude and hideous pictures printed from well-worn wood blocks, which had been used over and over again, and frequently applied to the most inappropriate subjects, Robinson

\footnotetext{
I Mr. Howard Pyle in Chap-book Heroes, printed in Harper's Nev Monthly Magazine, rol. Ixxxi. 1890.
} 
Crusoe being sometimes used for the Prodigal Son.' Many of the blocks that are used to illustrate chap-books have previously done duty in criminal histories, in Cock Robin series, and in the Cries of various towns, such as the Cries of London, of York, of Banbury, etc. Some have done duty with black letter tracts and ballads: as, for instance, I have seen a block of the Field of Flodden, which originally appeared with an account in black letter of the fight, doing duty with a chap-book. Large stocks of these wood blocks, many of great antiquity, were passed on by descent or purchase from one jobbing printer in London or the provinces to another. Thus Mr. Edwin Pearson writes :-

In 1708 John White, a citizen of York, established himself as a printer in Newcastle-on-Tyne, bringing with him a stock of quaint old euts, formerly his father's at York, when he was sole printer to King William, for the five northern counties of England. $\mathrm{He}$ entered into partnership with Thomas Saint, who on the death of John White, at their printing office in Pilgrim Street, succeeded in $1796(s i c)^{2}$ to his extensive business as printer, bookseller and publisher. In this stock of wood cuts were some of the veritable pieces of wood engraved or cut for Caxton, Wynken de Worde, Pynson, and others down to Tommy Gent-the curious genius, historian, author, poet, wood cutter and engineer, binder and printer of York. . . Thomas Saint about 1770, had the honour of introducing to the public, the brothers Thomas and John Bewick's first efforts in wood engravings, early and crude as they undoubtedly were. They are to be found in Hutton on Mensuration, and also in various children's and juvenile works, such as Esop's and Gay's fables. ${ }^{3}$

' In a collection of chap-books with the imprint of "Glasgow ; printed for the booksellers", we have found the same block, a dirine in black gown, bands and wig, doing duty as " the Rev. John Welch, minister of the Gospel at Arr," as "Thomas Wilcocks, author of Choice Drops of Honey from the Rock Christ, as "Donald Curgill, who was executed at the Cross of Edinburgh on the 26th July, 1680," as Dr. Isaac Watts, and as Mrahomet! After this one is not surprised to find in the same collection that William the Conqueror and William Wallace are represented by the same portrait, and that Dick 'Turpin, the famous highwayman, is dressed in the garb of a Turk, loose jacket, drawers and turban, and is armed with a scitaitur.
-White died 1769. See Halliwell's Fugitive Tracts and Chap-books, Fol. xxix. Percy Society, p. 77.

3 Banbury Chap-books and Nursery Toy Book Literature of the 18 th and early 19 th centuries, by Edwin Pearson. London: Arthur Reader, 1, Orange Street, Bloomsbury, W.C., 1890. The date 1796 in the quotation must be a misprint for some date anterior to 1770 . For the history of printing in Newcastle prior to the establishment of John White see two articles in the Archaologia Aeliana, second series, vol. vi. p. 225, by J. Hodgson Hinde, and rol. vii. p. 271, by James Clepham. From about 1666 to 1708 there was no resident printer in Newcastle. 
The Bewicks also did cuts for other printers of chapbooks, and for Newbery's series of Little Chap-books for Masters and Misses, such as Goody Two Shoes, and Tommy Trip, both of which were written by Goldsmith. ${ }^{1}$

The principal factory for them (chap-books) and from which nine-tenths of them emanated, was No. 4, Aldermary Churchyard, afterwards removed to Bow Cluuchyard, close by. The names of the proprietors were William and Cluen Dicey-afterwards C. Dicey only-and they seem to have come from Northampton, ${ }^{2}$ sain Hippolito and Dorinda 1720, the firm is described as Raikes and Dicey, Northampton. . . . From Dicey's house came nearly all the original chap-books. . . . Unscrupulous booksellers, however, generally pirated them very soon after issue, especially at Newcastle, where certainly the next largest trade was done in this class of books. The Newcastle editions are rougher in every way-in engravings, type and paper-than the very well-got-up little books of Dicey's. After the commencement of the present century reading became more popular, and the following, which are only the names of a few places where chap-books were published, shows the great and widely spread interest taken in their production :-Edinburgh, Glasgow, Paisley, Kilmarnock, Penrith, Stirling, Falkirk, Dublin, York, Stokesley, Warrington, Liverpool, Banbury, Aylesbury, Durham, Dumfries, Birmingham, Wolverhampton, Coventry, Whitebaven, Carlisle, Worcester, Cirencester, \&c. And they flourished, for they formed nearly the sole literature of the poor, until the Penny Magazine and Chambers' penny tracts and miscellanies gave them their death blow, and relegated them to the book-shelves of collectors. ${ }^{3}$

The "Garlands" were run out of the market by the competition of the Pinners-up and Long-song sellers. The Pinners-up used to take possession of dead walls, or the fronts of unoccupied houses, on which to affix their wares, consisting of yard long slips of new and popular songs, three slips a penny, while inside a huge open gingham umbrella they displayed a lot of cheap engravings. The Long-song sellers pasted three yards of songs together, and carried their wares about suspended from the top of a tall pole, crying "Three yards a penny, songs, beautiful songs, nooest songs".4

Akin to chap-books and distributed in the same manner

1 Banbury Chap-books and Nursery Toy Book, gc., pp. 2 and 30.

2 This was certainly so; in the British Museum is a unique specimen of a Northamptonshire chap-book ; it is The Life of Jonathan Wilde, Thief Taker General of Great Britain and Ireland, and the imprint is "Northamp- ton. Printed by W. Dicey, 1725"; see Northamptonshire Notes and Queries.

${ }^{3}$ Chap-books of the Eighteenth Century, bv John Ashton. London : Chatto and Windus, Piccadilly, 1882, p. 9.

4 See an article by G. A. Sa a, Street Ballads of the Past, in the Daily Telegraph, 1894. 
by chapmen, were horn-books and battledores. The original horn-book was,

A single leaf containing on one side the alphabet large and small, in black letter and in Roman, with perhaps a small regiment of monosyllables, and a copy of the Lord's Prayer, and this leaf was usually set in a frame of wood, with a slice of diaphanous horn in front, hence the name horn book. Generally there was a handle to hold it by, and this handle had usually a hole for a string, whereby the apparatus was slung to the girdle of the scholar. ${ }^{2}$

Shenstone alludes to the horn-book in his poem of The Schoolmistress :

Their books of stature sraall they take in hand,

Which with pellucid horn secured are

To save from fingers wet the letters fair.

From their shape they were also known as battledores. A child is represented as holding one, on the brass to Bishop Robinson (he died in 1616) which is in duplicate-in his cathedral at Carlisle and in Queen's College, Oxford, of which he had been Provost. These horn-books and battledores were superseded by little bocks, like chap-books, and hawked about by chapmen. To these books the names of horn-bookn and battledores came to be transferred, and by these names continued to be known long after their original form and shape, and so the reasons of their names, had been forgotten. They were also called absies (A.B.C.'s) and their contents were increased by the addition of graces before and after meat, of morning and evening prayers, prayers for relations, and such like matter : they came to be stitched in gaudy Dutch papers of flower and fruit designs, and to command the large price of four-pence and six-pence. ${ }^{3}$

The horn-book in its original form seems to have flourished down to the time of George II. Numerous as they must have been, copies are now most rare. ${ }^{4}$

1 The alphabet was generally preceded by a cross, whence it was called the Christ Cross Row, or Criss Cross Row, a term which was often used instead of horn book.

T The Book of Days, Chambers, vol. i. pp. 46,47 . British Archaological Journal, rol. ix. pp. 72 and 73, illustra. tions.

3 In the manuscript account books of the Archer family, quoted by Mr. Halliwell in his elaborate work on

Shakespeare, occurs this entry: "Jan. 3, 1715-16, one horn book for $\mathrm{Mr}$. Eyres, 00:00 : 02." The Book of Days, ut ante.

- Horn-books were also made of gingerbread :

To Master John, the English maid A horn-book gives of gingerbread, And that the child may know the better, As he can name, he eats the letter. Prior, Alma. 
But if chapmen carried about horn-books and battledores from which children could be taught their letters and their prayers, they also carried about lottery papers, which would teach them to gamble: two lottery papers are in the Bibliotheca Jacksoniana. These consist of sheets of small pictures, which were cut up by children and gambled for in some way which I do not understand, the currency employed being pins, then more valuable than at the present day.

It is foreign to our purpose to go fully into the general history of chap-books, and their relations, the horn-books, and the battledores. We merely purpose to give a few examples of various classes, selected from the collection of chap-books in the Bibliotheca Jacksoniana in Tullie House, Carlisle, reserring a full account thereof for the Transactions of the Cumberland and Westmorland Antiquarian and Archaological Society. ${ }^{1}$ This collection of chap-books was formed by the late Mr. W. Jackson, F.S.A., of Fleatham House, St. Bees, and was part of the Bibliotheca Jacksoniana, from which. after Mr. Jackson's death, it got accidentally severed, but to which it was restored through the kindness of a much interested friend.

The collection consists of 180 chap-books, issued from the various presses as follows :-

Carlisle

Whitehaven ...

Penrith $1 . .6 \quad \ldots 6$

$\begin{array}{lllllll}\text { Cumberland } & \ldots & \ldots & \ldots & \ldots & \ldots & 1\end{array}$

$\begin{array}{lllllll}\text { Workington } & \ldots & \ldots & \ldots & \ldots & \ldots & 2\end{array}$

$\begin{array}{lllllll}\text { Wigton } & \ldots & \ldots & \ldots & \ldots & \ldots & 1\end{array}$

$\begin{array}{lllllll}\text { Egremont } & \ldots & \ldots & \ldots & \ldots & \ldots & 1\end{array}$

$\begin{array}{lllllll}\text { Alston } & \ldots & \ldots & \ldots & \ldots & \ldots & 10\end{array}$

$\begin{array}{lllllll}\text { Kendal } & \ldots & \ldots & \ldots & \ldots & \ldots & 2\end{array}$

$\begin{array}{lllllll}\text { Ulverston } & \ldots & \ldots & \ldots & \ldots & \ldots & 3\end{array}$

$\begin{array}{lllllll}\text { Lancaster } & \ldots & \ldots & \ldots & \ldots & \ldots & 2\end{array}$

$\begin{array}{lllllll}\text { Newcastle } & \ldots & \ldots & \ldots & \ldots & \ldots & 4\end{array}$

$\begin{array}{lllllll}\text { Edinburgh } & \ldots & \ldots & \ldots & \ldots & \ldots & 1\end{array}$

$\begin{array}{lllllll}\text { Falkirk } & \ldots & \ldots & \ldots & \ldots & \ldots & 1\end{array}$

$\begin{array}{lllllll}\text { Kilmarnock } & \ldots & \ldots & \ldots & \ldots & \ldots & 3\end{array}$

$\begin{array}{lllllll}\text { London } & \ldots & \ldots & \ldots & \ldots & \ldots & 5\end{array}$

$\begin{array}{lllllll}\text { Derby } & \ldots & \ldots & \ldots & \ldots & \ldots & 1\end{array}$

$\begin{array}{lllll}\text { No place of printing given } & \ldots & \ldots & \ldots & 40\end{array}$

$\begin{array}{llllllll}\text { Glasgow } & \ldots & \ldots & \ldots & \ldots & \ldots & 6\end{array}$

See vol. xiv. pp. 1-126. 
The Bibliotheca Jacksoniana also possesses a collection of ninety-one chap-books, made by the late Mr. George Coward of Carlisle, and purchased at the sale of his library in November 1894. They are in brilliant condition, nearly all being uncut, and apparently never having been sold. Of these thirty-eight were printed at Newcastle-on-Tyne. all of them but two, by J. Marshall, in the Old Flesh Market: one of the exceptions is by "Angus, printer, Side, Newcastle"; the other, the history of The Lambton Worm, is by "W. R. Walker, Royal Arcade, Newcastle". The others are as follows :-

1. Printed at Morpeth by R. Blair.

1. Printed at Durham by G. Walker, junior.

1. Printed at Lancaster by C. Clark,

1. Printed and sold by W. and T. Fordyce, Newcastle and Hull ; and J. Whinham and Co., 66, Scotch Street, Carlisle.

This is a local ${ }^{1}$ chap-book and contains the Remarkable and Memorable History of Sir Robert Bewick and Laird Graham, of which the scene is laid at Carlisle.

34. Glasgow, printed by the booksellers.

1. No imprint.

8. Edirburgh, printed for the booksellers.

1. Stirling, printed for the booksellers.

4. Tain, printed for the booksellers.

1. London.

Crass I.

EXAMPLES OF GARLANDS OR COLLECTIONS OF SONGS AND BALLADS.

"A

GARLAND

OF

NEW SONGS

CONTAINING

The Perjured Maid.

A Song in praise of Free-Masonry.

The Dublin Baker.

Jem of Aberdeen."

"By"local" in this paper, Cumberland or Westmorland, or some place those two counties, is meant. 
Woodcut.-A large fly on a small table. This fly is from an early "Cock Robin" series: a similar one is attributed to Bewick, see Banbury Chap-books ; p. 20.

Imprint.-

\title{
"CARLISLE.
}

\section{Printed and Sold in Scotch Street."}

The first song has some local character; it mentions Maryport, Great Browton, and the parson of the parish, Mr. Bell. John Bell was vicar of Bridekirk, in which parish is Great Broughton, from 1755 to 1795. The perjured maid was one Jane White, of Maryport, who jilted a sailor, named Jimmy, for a sea-captain. The Dublin Baker is a highwayman under sentence of death.

\section{"FOUR NEW SONGS.}

\author{
I. A new Song, Briton's Lamentation. \\ II. Oxter my Laddy so Lang. \\ III. The Banks of Roses. \\ IV. The Bay of Biscay, O."
}

Woodcut.-A gentleman in maccaroni wig, and with three-cornered hat in hand, and a lady in a sacque with a fan and a gipsy hat.

Imprint.-

"CARLISLE.

Printed and sold in Scotch Street."

Briton's Lamentation refers to the War in America.

\section{"AN EXCELLENT GARLAND \\ CONTAINLNG THREE CHOICE SONGS.}

1. Westmorland Lass.

2. Roger the Miller.

3. The Highland Man's Song in praise of his Maggy, or the Bannocks of Barley Meal."

No Woodcut.

Imprint.-

"CARLISLE.

Printed by F. JOLLIE at the new printing office, Scotch Street." 


\section{“THE \\ DUKE OF GORDON'S \\ THREE \\ DAUGHTERS \\ To which are added : \\ John Uproar's Chant. \\ The Shepherd's Complaint. \\ Let Phillis be mine."}

Woodcut.-An interior from a much worn block; two men in wigs and pigtails, and two women in mobcaps, sitting over a fire. It has no apparent connection with anything in the chap-book.

Imprint.-

\section{"CARLISLE : Printed in Scotch Street, 17-"}

The hiatus in the date, is caused by the corner of the page being worn away, but an approximate date may be got from "John Uproar's Chant," which is a dialogue between a recruiting sergeant trying to raise recruits for the war in America, and a countryman, who takes the part of the Bostonians. This Chant is not likely to have been long popular, and we may refer its date, and so the date of the chapbook, to soon after the outbreak in Boston, say 1775 or 1776. "The Duke of Gordon's Three Daughters," is a favourite chap-book ballad, giving the story of how Jean Gordon married, against the Duke's will, one Captain Ogilvie : for his presumption Ogilvie was reduced to the ranks, but afterwards succeeded as Earl of Northumberland.

\section{"A \\ GARLAND \\ CONTAINING THREE EXCELLENT NEW SONGS. \\ I. The Indifferent Lover. \\ II. Thurot's Defeat. \\ III. A New Song."}

Woodcut.-A lady and gentleman at dinner : a servant stands behind the lady and a dumb waiter is at her side. Tail piece, a butterfly.

Imprint.-

\section{"Carlisle : Printed by W. HODGSON."}

The date of Thurot's defeat is 1760 ; see Hume and Smollett's History of England, vol. xiii. p. 215. It was made the subject of rejoicing carried to absurdity, and was long remembered and talked about. Forty-four years after it happened Lord Nelson wrote of Captain Elliot who defeated Thurot, "His action with Thurot will stand the test with any of our modern victories". Dictionary of National Biography. 


\section{"A \\ COLLECTION \\ $\mathrm{OF}$ \\ NEW SONGS \\ viz:}

1. The loss of the Centaur.

2. The Rambling Boy.

3. On the Supplementary Militia.

4. Allen's Return."

Woodcut.-A gentleman and lady in conversation. The lady wears the Fontange or Commode-head dress, which was in vogue in the latter part of the reign of William III and Queen Anne. The block itself may be of that date, or a copy from one of that date.

Imprint.-

\section{"A. BELL, PENRITH."}

The Centaur, 74 guns, foundered on her passage from Jamaica. Captain Inglefield and eleven only of the crew saved, Sept. 21, 1782. The Act for raising the Supplementary Militia was passed in 1796 and the men called ont in 1798 .

\section{"NEW \\ SONGS.}

The Crafty Maid.

The Young Man's Dream.

My Nanie $O$.

William and Phœbe."

Woodcut.-A woman with a basket on her head, very like one of the fignres in "The Cries of York . . printed by T. Kendrew, Collier Gate, York". The figures in the Cries of York were early and prentice work of the Bewick school and were afterwards used in "The Banbury Cries", see Banbury Chap-books, p. 47. The woodent on this chap-book is in all probability from the Bewick studio-the main difference between it and the figure in York Cries being the pattern on the basket.

Imprint.-

"PENRITH : Printed by A. Bell, 1804."

\section{"NEW \\ SONGS.}

1. The Ploughboy.

2. The Rambling Boys of Pleasure.

3. Bonaparte and Talleyrand.

4. The Corsican Fairy." 
Woodcut.-A figure in tail coat and knee breeches leaning on a pedestal, on which is a funeral urn.

Imprint."PENRITH : Printed by Ann Bell, 1804."

Class II.

\section{EXAMPLES OF RELIGIOUS AND MORAL CHAP-} BOOKS.

\section{"A TRUE AND FAITHFUL ACCOUNT OF THE MANNER OF CHRIST'S coming to JUDGEMENT} On the LAST DAY.

Shewing in what Manner the Dead shall be raised with a particular Account of the glorious Reward of the Righteous, and likewise the Torments to the Wicked and Evil Doers."

Woodcut.-A very rude one of the Resurrection; our Saviour, nimbed, is seated on a rainbow with his feet on the clouds, and his hands open, palms to the front. The sun and moon are on either side of him, and below are two cherubims; at the bottom the dead rise naked from their graves.

The imprint.-

\section{"CARLISLE : Printed in the year 1770."}

This booklet of eight pages is by way of question and answer, of which the following are samples :-

"Q. Who will dread the coming of Christ?

A. The murderer, who slew his brother; the adulterer who satisfied his lust with beauty; the swearers who open the wounds of Christ; and the drunkards who drink their bodies health while they ruin the soul.

Q. And what comfort shall such offenders find at the day of judgment?

A. Sad comfort shall they have when sentence of condemnation is passed upon them, then shall the murderer be for execution, and buried in the hottest pit in hell. The adulterer shall satisfy his lust when he lies on a bed of fire. The drunkard has enough of drink when scalding lead is poured down his throat. The swearer has enough of wounds and blood tortured (sic) his body and soul in flames." 
The cut is from a very worn block, which might almost be mediaval; it fits the subject of the chat-book excellently, indeed one of the answers is "Jesus Christ cometh in a terrible manner, for he rides upon the wings of the wind, his seat is a rainbow, and the clouds his foot-stool ". We find this block afterwards in the hands of Frapcis Jollie, jr., at Penrith.

\section{“TWO TRUE AND REMARKABLE STORIES. PATIENT JOE, OR THE AWFUL DEATH OF TIM JENKINS.}

\section{THE \\ POWER OF CONSCIENCE."}

Woodeut.-St. George and the Dragon.

Imprint.-

"Carlisle: Printed by F. Jollie and Sons."

Patient Joe, is a story of a pious Derbyshire collier, who always considered that everything was for the best. The Power of Conscience is a tale of a servant.

\section{“THE HISTORY OF JOSEPH \\ AND HIS \\ BRETHREN \\ WITH \\ JACOB'S JOURNEY INTO EGYPT \\ AND HIS \\ DEATH AND FUNERAL."}

Woodcut.-Two standing figures, one with a staff. Imprint.-

\section{" WHITEHAVEN}

Printed and sold by J. BRISCOE.

Price Cne Penny."

This is a long doggerel poen, which is printed in Ashton's book from a copy with numerous cuts. Briscoe's edition has none but the one on the title page, but it has at the end. 
“THE

SOLILIQUY [sic]

OF

ABRAHAM

UPON RECEIVING

THE COMMAND TO SACRIFICE

HIS

SON ISAAC"

The Woodcut.-The Roman soldiers at the empty tomb, over which is an angel.

“THE

IIFE and DEATH

$\mathrm{OF}$

MRS. JANE SHORE

CONCUBINE TO

KING EDWARD IV."

Woodcuts.-On title page is a cut representing a yard or a bakehouse. There are two cuts in the text; one a lady, Jane Shore, in a coach, and the other a ghastly shrouded female figure in a coffin.

Imprint.--

"WHITEHAVEN

Printed and sold by J. BRISCOE, in the Market Place."

A favourite subject for a chap-book, it having a moral ending in Jane Shore's unhappy death, see Ashton, p. 393.

“THE

WANDERING JEW,

OR THE

\section{SHOEMAKER OF JERUSALEM.}

Who lived when our Lord and Saviour Jesus Christ was crucified; and appointed by him to live till he comes again. Together with his Travels, manner of living and what he has seen. To which is added, his true description of Christ." 
Woodcut.-A man with bundle on a stick, standing outside of a cottage.

Imprint.-

\section{WHITEHAVEN}

Printed and sold by T. WILSON, King Street."

The Wandering Jew is also a favourite chap-book subject, of which there is another edition in the Collection.

\section{"THE \\ DANGER \\ $\mathrm{OF}$ \\ EVIL COMPANY.}

' Train up a child in the way he should go, and when he is old he will not depart from it."

No woodcut.

Imprint.-

"WHITEHAVEN

Printed by T. NICHOLSON, Roper Street, 1856."

“ THE

NEW GAME OF CARDS,

OR A

PACK OF CARDS

Changed into complete and perpetual

ALMANACK

In a Dialogue between a

NOBLEMAN and his SERVANT.

First, showing the use of an Almanack by the Quarter :-Secondly, showing the Weeks and Days of the Year:And thirdly, showing the exact Number of Hours and Minutes in a year-Fourthly, showing how it may be converted into a Prayer Book, with curious Remarks on the Knave. The whole adapted to the Entertainment of the Humourous, as well as to the Satisfaction of the Grave, Learned and Ingenious. The like never before published."

Woodblocki-A swan to the left, probably a Bewick block.

Imprint.-

“A. Rell, printer, Penrith, 1797." 
“CHRIST'S CARE OF HIS PEOPLE UNDER

AFFLICTING DISPENSATIONS.

\author{
TWO \\ SERMONS \\ PREACHED
}

On the Seventeenth Day of August, 1662.

FROM MATTHEW XIV. 24, 25, 26.

BY

MR. WILLIAM GUTHRIE.

AUTHOR OF

"The Trial of a Saving Interest in Christ"

and

Minister of the Gospel at Finnick.

Psalm CXXV. 1.

They that trust in the Lord shall be as Mount Zion, which cannot be moved, but abideth for ever.

Psalm CXXXVIII. 17.

Though I walk in the midst of Trouble, thou wilt revive $m e . "$

No uoodcut.

Imprint.--

" PENRITH

Printed and sold by Ann Bell.

1804."

Twenty-four pages. William Guthrie was a Scotch Presbyterian divine 1620 to 1665 . He had a call to Fenwick (or New Kilmarnock), and from his manner was frequently called the "Fool of Fenwick" even on the title page of some of his sermons. His notice of him and a list of his writings is in the National Dictionary of Biography.

\title{
،. THE \\ SINNER'S \\ REDEMPTION.
}

Wherein is discovered The Nativity of our Blessed Lord and Saviour, JESUS CHRIST, Together with his 
Life on Earth, and Death upon the Cross, for lost mankind."

Woodblock-Head of a pope, triple tiura and pastoral staff.

Imprint.-

"PENRITH: printed and sold by ANN BELL."

“BRITAIN'S

TIMELY REMEMBRANCER,

OR A

WARNING FROM HEAVEN

TO

VILE SINNERS ON EARTH.

BEING

MR. BRIGHTLY'S last SERMON which

he preached in his shroud, and died immediately after he concluded the same.

To which is Added

An account of the holy life of Mr. R. Brightly, Minister of Waltham in Leicestershire, and of his daily walking with God. Of the care he took of his Parishioners. during their visitation with many malignant distempers. How he was praying one night at his chamber window. he fell into a trance, and saw the state of the damned in everlasting torments, and that of the blessed in celestial glory,-O Of his being warned of death by an Angel: he afterwards bought a shroud and coffin, his grave to be made, and invited his Parishioners to attend his last sermon-When he declared his vision, how he saw Death, and of the message he had given him to warn the inhabitants of the earth from the wrath to come. Of his dying in the pulpit when he had delivered his sermon. And lastly of his burial, and the harmonious music that was heard in the air during his interment."

Woodcut.-None.

Imprint.-

"PENRITH.

Printed and sold by ANN BELL in the Market Place."

This chap-book is given by Halliwell in his "Fugitive Tracts and chap-books," vol. 29, Percy Society. 
“ THE

AGE OF MAN

OR

MAN'S BEGINNING AND LAST END, DESCRIBED IN THE CHARACTER OF

LIFE AND DEATH,

Setting Forth

The Uncertainty and Brevity of Man's Life.

Also, many serious and awaking considerations to careless Souls, to prepare for the last enemy Death.

Thou fool, this night shall thy soul be required of thee. Luke XII.-20."

Woodcut.-None.

Imprint.-

"PENRITH, printed and sold by A. Bell."

\author{
"A \\ KEY \\ TO OPEN \\ HEAVEN'S GATE, \\ OR, A READY \\ PATH-WAY \\ TO \\ HEAVEN.
}

BY LAWRENCE PRICE.

Come ye blessed of my Father, receive a Crown and Kingdom of Glory, which was prepared for you from the Beginning."

Woodcut.-None.

Imprint.-

"Printed by ANN BELL, PENRITH." 
"A

WONDERFUL CONTRACT NOW BEGUN

BETWEEN TWO PARTIES OF GREAT RENOWN;

JEHOVAH the BRIDEGROOM

AND

HIS CHURCH THE BRIDE.

This I compos'd in dead of night,

While on my bed I did reflect;

And who inclines to read these lines,

My advice will not neglect."

Woodcut.-A small ornament.

Imprint.-

"Printed by A. BELL, PENRITH."

A long poem.

“DEATH'S WARRANT;

OR THE

SOUL'S WELCOME

TO

GLORY.

WRITTEN BY

JOHN BROWN.

A young man in Hexham, on his Deathbed, and sung at his Funeral, at his own Request.

To which is added

THE LIFE OF THE

HAPPY MAN."

Woodeut.-None.

Imprint.-

“PENRITH : printed by A. BELL." 
"HEAVENLY REST

FOR A

WEARY SOUL

. OR, THE

\section{PILGRIM AT HIS JOURNEY'S END}

\section{BEING}

THE LAST LEGACY OF A FATHER TO HIS CHILDREN, WHEN ON HIS DEATH-BED

TO WHICH IS ADDED

I. The Children's Duty to God, their Mother and Themselves.

II. A Copy of Verses, written by the Father, a little before his Death.

III. Some Godly Meditations.

IV. The Father's last gift to his children.

By the Rev. JOHN BUNYAN."

Very pleasant to read, profitable to practise, and of Excellent Use to all Sorts of People, that desire to live a godly life in this present World.

Woodcut.-None.

Imprint.-

"PENRITH : Printed and Sold by Aun Bell."

" AN

ADDRESS

TO

PARENTS, \&C.

Shepherd of souls with pitying eye

The thousands of our Israel see

To thee in their behalf we cry,

Ourselves but newly found in Thee

We tremble at the danger near,

And crowds of wretched parents see ;

Who blindly fond, their children rear

In Tempers far as Hell's from Thee." 
Woodcut.-Figure of Time with scythe and hour-glass. Above a mason's level, and below another and a pair of compasses.

Imprint.-

" PENRITH.

Printed by Anthony Soulby.

In the Market Place."

"THE

PARENTS' PIOUS GIFT

OR

A CHOICE PRESENT FOR CHILDREN

SET FORTH IN

A DIALOGUE between a RELIGIOUS FATHER, and an EXTRAVAGANT SON.

TO WHICH IS ADDED

A HYMN on the DAY OF JUDGMENT."

Woodblock.-The last judgment from Carlisle chap-book of 1770 .

Imprint.-

"Printed at the New Printing Office, PENRITH."

“ THE

AFFECTING HISTORY

$\mathrm{OF}$

SALLY WILLIAMS

AFTERWARDS CALLED

TIPPLING SALLY.

Shewing how she left her father's house to follow an Officer, who seduced her, and how she took to drinking, and at last became a vile Prostitute, died in an Hospital, and was dissected by the Surgeons.

TENDING TO SHEW THE PERNICIOUS EFFECTS OF DRAM DRINKING."

Woodcut.-None.

Imprint.--

" PENRTTH.

Printed by F. JOLLIE, Junr.

Of whom may be had Moral and Religious Tracts.

(Price one penny.)" 


\section{"THE SINNER \\ DIRECTED TO \\ THE SAVIOUR \\ (An Extract from Favel.)"}

Woodcut.-The Crucifixion.

Imprint.-

"PENRITH.

PRINTED BY J. ALLISON.

Of whom may be had

A large and general Assortment of Religious Patters, Children's . Books, Histories, \&c., \&c.

PRICE ONE PENNY."

\section{“ THE \\ PRODIGAL SON \\ IN VERSE.}

Shewing how a young gentleman spent his money in riotous living, and was afterwards reduced to feed Swine, when being almost starved, he returned to his father, who kindly received him, and made a great feast on the occasion." bead.

Woodblock.-A figure in a landscape, apparently mopping his

Imprint.-

"PENRITH

PRINTED BY J. ALLISON.

Of whom may be had

A large and general Assortment of Religious

Patters, Children's Books,

Histories, etc., etc.

PRICE ONE PENNY:' 
" THE

\section{PIOUS HERMIT}

OR

Mysterious Providences Unriddl'd.

TO WHICH IS ADDED

\section{THE CHARACTER OF CHRIST."}

Woodcut.-A figure in gown and round cap, like a doctor of law, and with something like a turnip in his hand, is apparently going to feed a reclining stag.

Imprint. - As on last.

\section{“ THE \\ HISTORY \\ $\mathrm{OF}$ \\ WILLIAM BLACK \\ A CHIMNEY SWEEPER."}

Woodcut.-A figure in black looking at a funeral urn on a pedestal.

Imprint.-As on last two.

UNHAPPY BIRTH,

WICKED LIFE, AND MISERABLE DEATH OF THAT VILE TRAITOR AND APOSTLE

\section{JUDAS ISCARIOT}

Who killed his reputed brother, murdered his own father and married his own mother; and for thirty pieces of silver betrayed his most sacred Lord and Master JESUS CHRIST."

Woodblock.-None.

Imprint.-None.

" HYMNS

AND

SPIRTTUAL (sic) SONGS."

Woodblock.-A man in full bottomed wig and full skirted coat.

Imprint.-None.

But in the place usually occupied by it is : 
"This Author of this, Erix Arglestom in Swedish, and Alexander Johnson in English, was born in Stockholm, the metropolis of Sweden."

The inner leaves of this chap-book of eight pages are lost, but the first hymn is headed "Christ's Sufferings in his Birth," and the last must be, judging from what remains, "Christ's Sufferings in his Death."

“GOD'S DREADFUL JUDGEMENT

$\mathrm{ON}$

WICKED, CRUEL AND DISOBEDIENT CHILDREN

TO THEIR

PARENTS.

Shewing how a farmer of Exeter reduced himself to extreme poverty in order to advance his son by marrying a lady of fortune; how the son having accomplished his Design, disdained his father and mother, who soon after died with grief. Also the miserable death of this undutiful wretch."

Woodblock.-Head of a divine.

Imprint.-

"Newcastle, Printed in the Present year."

Class III.

EXAMPLES OF HISTORICAL CHAP-BOOKS.

“THE FAMOUS AND RENOWNED

HISTORY

OF THE MEMORABLE, BUT UNHAPPY HUNTING OF CHEVY CHACE

NEAR THE

RIVER TWEED IN SCOTLAND

TOGETHER

With the great and mortal battle fought between the lord PIERCY Earl of Northumberland, and his fifteen hundred English Archers, and Earl DOUGLAS with twenty hundred Scottish spearmen : in which both these Earls, with most of their men were slain." 
Woodcuts.-On title page half length of man in armour and full bottomed wig, star on breast and baton in right hand; qu : Marlborough : two cuts of modern sport, namely horseman and dogs chasing a deer, and a gunner with dead hare and a dog: also two or three cuts from J. Dunn's Tom Hickathrift, notably the ballet of six men in armour: see Class VII.

Imprint.-

"WHITEHAVEN

Printed by ANN DUNN, Market Place."

This is a prose, not a poetical account of the celebrated hunting.

"CHEVY CHACE'S GARLAND

Or, an unhappy memorable OLD SONG.

Shewing the Hunting of Chevy Chace, between the Earl Piercy of England, and Earl Douglas of Scotland."

Woodblock.-Two horsemen, like fox-hunters of last century, and a huntsman on foot with horn and leaping pole, and three dogs pursue a hare. In background a house, and a female figure with a shield, and a fiail : qu : a quintain? qu : a female with spinning wheel and distaff? A similar wood cut is in Charnley.

Imprint.-

"Licensed and Entered according to Order."

"An Excellent

NEW SONG

Called

THE BATTLE OF TRAFALGAR

Or

THE VICTORY AND DEATH OF

LORD NELSON.

Never before published

To which are added

TROTTING ALONG THE ROAD

AND A

Song for the WEDDING NIGHT"

Woodcut (small).-A ship.

Imprint.-

"PENRITH :

Printed and Sold by A. Soulby." 


\section{“THE}

LIFE AND DEATH

$\mathrm{OF}$

FAIR ROSAMOND.

Concubine to King Henry the Second."

Woodcut - A lady and gentleman, each with a fan, she in a hnge hoop and sacque.

Imprint.-

" PENRITH :

PRINTED BY F. ALLISON.

Of whom may be had

A large and general Assortment of Religious Patters, Children's Books, Histories, \&c."

Class IV.

CHAP-BOOKS OF ADVENTURE.

"THE

LIFE

AND

SURPRISING ADVENTURES

$\mathrm{OF}$

FREDERICK BARON TRENCK,

CORRECTED AND ABRIDGED

TO WHICH IS ADDED

A SHORT SUPPLEMENT:

Giving an authentic account of his more recent 'Iransactions, till he fell a victim to the prevailing system of Anarchy in France, being sentenced to the Guillotine by the French Convention."

Woodcut.-A cavalier in full bottomed wig on horseback; his hat has fallen off.

Imprint.-

"PENRITH:

Printed by Ann Bell." 
“CRAWFORD'S TRACTS

No. 1.

THE

NEGRO SERVANT.

\author{
AN \\ AUTHENTIC NARRATIVE \\ $\mathrm{OF} \mathrm{A}$ \\ YOUNG NEGRO
}

Shewing

How he was made a slave in Africa, and carried to Jamaica, where he was sold to a Captain in His Majesty's Navy, and taken to America, where he became a Christian; and afterwards brought to England and baptized."

Woodblock.-A kneeling negro in chains.

Imprint.-

"KILMARNOCK.

PRINTED BY H. CRAWFORD."

“THE BRAVE

BRITISH TAR

OR

The true history of a sailor who had both his legs shot off in Lord Duncan's Victory, with an account of his extraordinary dream, and how remarkably it was fulfilled."

Woodblock.-A brigantine : probably by Bewick.

Imprint. -

" KENDAL.

II. and R. BRANTHWAITE, PRINTERS."

A pious tract: converted Sailor. 
" THE HISTORY

$\mathrm{OF}$

\section{HONEST JACK}

\section{THE SAILOR}

"We should think of the world that's to come, honest Jack

When in this we're so pain'd and perplex'd."

"O no! this world for me, for I don't know, you see, At all what to think of the next."

Woodblock.-A scene on a quay; probably a Bewick block.

Imprint.-

"KENDAL.

Printed by M. and R. Branthwaite."

THE

UNFORTUNATE SHIPWRIGHT

OR

CRUEL CAPTAIN

BEING A

FAITHFUL NARRATIVE

of the Unparallelled Sufferings

of

ROBERT BARKER

Late carpenter on board the Thetis Snow, of Bristol, on a Voyage from thence to the coast of Guinea and Antigua."

Woodblock.-None.

Imprint.-

\section{"LONDON.}

Printed for and sold by the SUFFERER for his own Benefit, and by no one else, 1775 .

(Price $8 d$. or $4 d$. each part.)"

There are thirty-eight pages to this chap-book, and have been more. It has a full page portrait of the sufferer in his prime, standing on a quay, and viewing a two-masted ressel, intended for the Thetis Snow. 
“THE

LIFE,

VOYAGES, AND SEA BATTLES

$\mathrm{OF}$

THAT CELEBRATED SEAMAN

COMMODORE

PAUL JONES,

Still remembered

By some of the Old Inhabitants

Now living at Wapping,

He being originally in the coal trade,

In which is contained

A variety of important facts

Displaying the

Revolutions of Fortune that this Naval Adventurer underwent.

DERBY

PUBIISHED BY THOMAS RICHARDSON

SIMPKIN, MARSHALL \& CO., LONDON.

PRICE SIXPENCE."

This booklet has a brilliantly coloured folding picture, giving scenes in the life of Paul Jones. It has twenty-four pages, and is rather more than a chap-book.

CLAsS V.

ROMANTIC OR POETICAL CHAP-BOOKS.

"HISTORY

$\mathrm{OF}$

DORASTUS AND FAUNIA

SETTING FORTH THEIR

LOVES, MISFORTUNES AND HAPPY

ENJOYMENT OF EACH OTHER

AT LAST."

Woodcuts.-On the title page a hideous angel with outstretched arms stands before three seated figures engaged in animated conver- 
sation. In the text are several other cuts, as head and tail pieces to chapters :- a bird ( $q u$. a parrot) on a stump, a ship under sail; a post-boy on horseback blowing a horn, and galloping to the right; an interior, five seated figares, two males, three females; block too worn for details of costume to be made out; another post-boy on horse-back with large valise behind him, galloping to the left; a sheep; John Gilpin galloping past the Bell at Edmonton; a horse soldier of the last century in three-cornered hat and jack boots; and another bird (qu. a thrush). The two birds and the sheep may have come from some pictorial alphabet; or the birds from a cock robin series; the second postboy is a copy, probably by an apprentice, of a Bewick block, see Banbury Chap-books.

Imprint.-

\section{"CARLISLE, PRINTED BY F. JOLLIE."}

The chap-book of twenty four pages is a romance, the history of how Pandosta, King of Bohemia, was jealous of Bellaria, his Queen and Egistus, King of Sicily ; the crimes he consequently committed, and the happy union at last of his daughter Faunia, with Dorastus, son of Egistus. One fails to see the connection of John Gilpin with the story, but as "John Gilpin" was written by Cowper in 1782, this chap-book cannot have been printed earlier, and was probably printed much later, say about 1800 .

\section{"THE CONSTANT LOVERS}

\section{GARLAND, \\ IN FOUR PARTS.}

Part I. Shewing how beautiful Nancy of Yarmouth feil in Love with Jemmy the Sailor.

Part II. How the Father convey'd a Letter to destroy young Jemmy his Daughter's Sweetheart.

PART III. How the Ghost of young Jemmy the Sailor appeared to Beautiful Nancy.

ParT IV. How the Ghosts of these two unfortunate

Lovers appeared to the Boatswain, and he being tried, was hanged at the Yardarm."

Woodcut.-A male figure seated under a tree, while a female figure stands by and harangues him.

Imprint.-

\section{"WHITEHAVEN.}

Printed in the year MDCCLXXX."

A long and dismal ballad, the nature of which is well explained in the title : but its popularity is proved by the number of printers that included it in their chap-books. 


\author{
"A \\ NEW SONG \\ CALLED \\ SWEET WILLIAM \\ $\mathrm{OF}$ \\ PLYMOUTH."
}

Woodcut.-A very rude cut of an action between a fort on a cliff and two men of war. The fort flies a standard with a plain cross next to the staff and may be intended for the English standard prior to the Union with Scotland, which would make the block date from the sixteenth century. One of the men-of-war displays an immense ensign, covered with horizontal stripes. Nothwithstanding this, I think this block is intended to represent the Siege of Belleisle, it being used on Penrith and Glasgow chap-books containing an account of that siege.

Imprint.-

"PENRITH. Printed and sold by A. Bell."

\author{
“ THE \\ PERJURED \\ GARLAND, \\ SHEWING
}

How a young lady, near Exeter, forswore herself for the sake of Riches; with an Account what an Example she was made which it is hoped will be a Warning to all young People."

Woodcut.-The action between a fort and two men-of-war as in last instance.

\title{
"ANTONIO \& CLARISSA \\ OR THE \\ FATAL POEM.
}

A

\section{PATHETIC TALE}

An account of an unfortunate young

LADY, \&c."

Woodcut.-A gentleman and lady with fan.

Imprint.-

"PENRITH. Printed by Ann Bell."

This is a dismal story: the heroine, Miss Clarissa Williams, is the daughter of an eminent physician in the north, whose house is a few miles from Whiteharen, where Clarissa was at school. 
“THE

\section{GOODHURST GARLAND}

IN THREE PARTS.

Part I. The loyal courtship between a sailor and a farmer's daughter.

Part II. The sailor's mother's passion for her son's pretending to marry the farmer's daughter, who she thought much below his fortune.

Part III. The sailor's wedding, who took his bride home in such rich garments that his mother took her for a fine lady."

Woodcut.-Five stars or asterisks, cross-wise.

Imprint.-

" PENRITH.

Printed and sold by ANN BELL."

"THE UNNATURAL FATHER'S

GARLAND

OR THE

DUTIFUL SON'S REWARD.

In Three Parts.

Part I. Shewing how a gentleman in Dorsetshire had two sons, one of which he had an aversion to, and turned him out of doors.

Part II. How his darling son by extravagant living brought, his father to poverty.

Part III. How the son whom his father hated, after sometime being abroad, married a rich lady with whom he came to England, and relieved his sorrowful father from great distress."

Woodcut.-None.

Imprint.-

“PENRITH.

Printed and sold by ANN BELL." 
"JAMIE AND NANCY
OF

YARMOUTH, SHEWING

THEIR CONSTANT LOVE TO EACH OTHER UNDER THE SEVEREST CRUELTY."

Woodcut.-A sailor with his arm round a girl points to a ship in the offing.

Imprint.-

"PENRITH.

Printed and sold by A. BELL."

“THE WESTERN. GARLAND

In Four parts.

Part I. William Whitecraft's courtship to Mrs. Susan Cole, both of Plymouth; with an Account of her Sickness, which disappointed the Wedding.

Part II. The Deceitfulness of her Parents, who sent her to Holland, because she would not marry a Squire, and break her former vows.

Part III. William's great Fortune in obtaining Riches, with the Account of Susan's pretended Death which afterwards he found to be the Deceitfulness of her Parents in finding her by good Fortune at the Hague.

Part IV. His return to England with his Lore, with an Account of their happy Wedding : concluding with the pleasant Pastime between the Parents and the Daughter, while they did not know their Child, though in their Presence."

Woodblock.-A ship.

Imprint.- "Licensed and Entered according to Order." 


\section{"THE \\ GOLDEN BULL, \\ OR THE \\ CRAFTY PRINCESS.}

In four parts.

Part 1st. How a King Courted his own Daughter for marriage, threatening her with Death if she would not ccnsent to be his Wife.

Part 2nd. The Lady's Craftiness to be conveyed over Sea in a Golden Bull to the Prince she loved.

Part 3rd. How her Arrival and Love came to be known to the young Prince.

Part 4th. How her Death was contrived by three Ladies in her Lover's absence. How she was preserved and after married to the young Prince, with other remarkable incidents that happened."

Woodblock.-A king and a queen.

Imprint.-

" Entered according to Order."

"THE

SON OF ALKNOMOCK

AND THE

DEATH OF ALICO

To which is added

The African's Complaint on Board a

Slave Ship and

THE NEGRO BOY."

Woodblock.-An Indian in feathered head-dress smoking a long pipe, with his hand on a hogshcad.

Imprint.-

" Entered according to Order."

A chap-book of eight pages. 
Class VI.

CRIMINAT CHAP-BOOKS.

"AN

ACCOUNT

OF THE

EXECUTION

$\mathrm{OF}$

STOKES ALIAS STOCKTON

AND

EDWARDS,

Tried at the last Carlisle Assizes, 1809,

FOR THE

ROBBERY

OF THE

WHITEHAVEN BANK."

Woodblock.-None.

Imprint.-

"WIGTON.

Printed by R. HETHERTON."

At the end is : Printed at Hetherton's Office Wigton.

\section{A DREADFUL WARNING \\ TO \\ DISOBEDIENT CHILDREN}

Being an awful Account of the Life, Trial, Confession and Execution of,

\section{JOHN HARRISON}

Aged 20 of Wigton, near Carlisle, who was Executed for the Wilful Murder of his Father, Mother, and Servant Maid; for robbing the house, and setting fire to it, with an intent to hide the crime.

With the manner of the discovery, his apprehension, what confession he made before the Magistrates. How the Ghosts of the dead bodies appeared to him in gaol. 
Together with his dying speech at the place of Execution : with several other things worthy the observation of young people."

Woodcut.-A small rural scene. In the text is a portrait of the murderer.

Imprint.-

" LONDON :

Printed by J. Evans \& Son, 42, Long Lane, West Smithfield,

Price One Penny."

“THE BERKSHIRE

TRAGEDY

OR

\section{THE WHITTAM MLLER.}

Who most barbarously murdered his Sweetheart: With his Examination, Confession and Trial. Likewise his last dying Words at the Place of Execution."

Woodblock.-A rude and hideous representation of a man cutting a woman's throat. This cut is reproduced in "Specimens of Early Wood engraving from the Collections of Mr. Charnley, Newcastle, printer, printed Newcastle 1858."

Imprint.-

"Licensed and Entered according to Order."

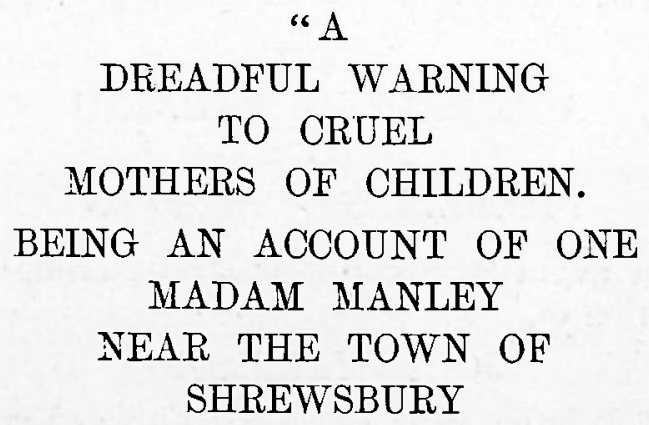

Who was burnt at a Stake for the murder of her own child, a Daughter, of about ten years of Age."

Woodblock.-A man hanging from a gibbet. Inside are three, one of which represents a parson, a lady and the devil.

Imprint.-

"Licensed and Entered according to Order." 


\title{
"DREADFUL NEWS FROM CUMBERLAND BEING
}

A true Relation of a most horrid and barbarous Murder committed the 18th of April 1753; shewing one William Johnson, a Butcher, went to Mr. Wilkinson's a Grazier, near Wigton in the county of Cumberland, to buy Cattle and found the said Mr. Wilkinson, his Wife, three daughters marriageable, three small children, a Nurse and a Man servant, all inhumanly murdered in their Beds, and weltering in their Gore. With an account of the wonderful Discovery of the Murderers, their apprehending and Commitment to Carlisle Gaol.

With the substance of a SERMON preached on this sad Occasion by the Rev. 1Kr. James Duuglas, Minister of Wigton.

In a LETTER to a GENTLEMAN."

Woodblock.-Two small flowers.

Imprint.-

"Licensed and Entered according to Order."

As the Sermon is said to have been preached in Wigton Church, "Minister" must mean, vicar, but no vicar of Wigton was ever named Douglas. The whole story is a flam, from beginning to end.

\author{
“ TRIAL. \\ OF \\ JOHN HATFIELD \\ FOR \\ FORGERY \\ WITH AN
}

ACCOUNT OF HIS BEHAVIOUR

WHILE UNDER SENTENCE OF DEATH

TO WHICH ARE ADDED

AN

INTERESTING LETTER TO MIR.-

AND OTHER

PAPERS AND LETTERS." 
No woodcut.

Imprint.-

" PENRITH

Printed and Sold by Ann Bell.

Price Three halfpence.

1803."

Unluckily only the first and last leaves of this interesting local chap-book of 24 pages remain : the rest being lost. Hatfield was tried at Carlisle, August 15th, 1803, and hanged shortly afterwards.

Class VII.

\section{CHAP-BOOKS CONTAINING LEGENDS AND STORIES.}

\section{"A PLEASANT AND DELIGHTFUL HISTORY \\ $\mathrm{OF}$}

THOMAS HICKATHRIFT."

Woodcuts.-On the title page an uncouth figure of a giant, round hat or cap in hand, own hair loose, and costume of the period of George II.

The text contains several other rude cuts, which have little to do with the subject matter, and the whole of the last page is taken up with a woodcut in three compartments : in one two fgures on horseback tilt at one another : in the second are two figures, one standing over the other, wholies upon the ground : in the third two large dogs or wild beasts charge a giant, who thrusts a hand down each of their throats. ${ }^{1}$ The cut on p. 13 is a rude reproduction of a cut of Crispin and Crispianus, from the Shoemaker's Glory, a chap-book whose imprint is "Newcastle: Printed at the Printing Office in Pilgrim Street."

Imprint.-

" WHI'CEHA VEN

Printed and Sold by J. DUNN."

1 This is a copy from the title page of The Fameous History of the Taliant London Apprentice, whose imprint is
"Newcastle: Printed in this present year." Ashton, p. 227. 


\section{"The SECOND PART OF THOMAS HICKATHRIFT."}

Woodcut.-The same as on the last, page of the first part : other cuts from the first part are reproduced in the second part equally apropos of nothing in the text. A rude cut of either Charles II, James II or William III, crowned, robed, and vastly bewigged, does duty for the King of the story, William I. A cut of a sort of ballet dance of six figures in armour, and brandishing cutlasses represents the twenty-one ruffians in armour who attacked Hickathrift.

Imprint.-There is none, but this second part is clearly from tho same press as the first part with the imprint of J. Dunn.

The history of Thomas Hickathrift is one of the best known of chap-book stories; he is said to have lived in the Isle of Ely, in the time of William the Conqueror. Part I. tells how by his strength and valour he arose from a poor man's son to be Mr. Hickathrift; and Part II., how he came to be Sir Thomas Hickathrift, and died of grief for the loss of his friend Henry Nonesuch, the Tinker. Mr. Ashton prints Part I. of the History of Thomas Hickathrift, and says "This worthy does not seem to have been an absolute myth."

Cunningham prints both parts."

“ THE

HISTORY

OF THE

\section{KING and COBLER."}

This is a chap-book of twenty-four pages, whose first and last pages are gone; it is the first part of the History of the King and Cobbler, a well-known chap-book story, which is given by both Ashton (p. 232) and Cunningham (p. 1). There is no imprint, but in the text are several cuts which appear in the History of Tom Hickathrift, including the giant which did duty on the title page for Tom; it now represents the cobbler going to conrt. A cut of a lady and gentleman in costumes of end of seventeenth century, represents the cobbler and his wife Joan. What the cut really represents is a puzzle at present: above the lady's head are the letters R.M. while three cherubims blow zephyrs upon the gentleman's head from the upper right corner of the cut. The letters R.M. appear on other woodblocks used by the Dunns.

I Chap-books of the Eighteenth Century, p. 193. London: Chatto and Windus, 1882.
2 Amusing Prose Chap-books. London : Hamilton, Adams and Co., 1889. 


\title{
"The SECOND PART of the HISTORY OF THE
}

KING and the COBLER."

Woodcut.-The cut of a King which did duty for William I. in the History of Tom Hickathrift.

Imprint.-

"WHITEHAVEN

Printed and Sold by J. DUNN."

\section{"THE \\ HISTORY \\ OF ADAM BELL, CLIM OF THE CLOUGE AND \\ WILLIAM OF CLOUDESLIE. \\ THE THREE NORTHERN \\ ARCHERS."}

Woodcut.-An archer in a modern costume, hat and feathers.

Imprint.-

"Anthony Soulby, printer, Penrith."

The scene of this ballad is laid at Carlisle.

\author{
"THE \\ EXCELLENT OLD BALLAD \\ $\mathrm{OF}$ \\ THE THRIFTLESS \\ HEIR OF LINN \\ AND \\ JOHN OF THE SCALES \\ IN TWO PARTS."
}

Woodcut.-In an oval frame, a young head, plumed hat; $q u$. Fdward VI.

Imprint.-

"SOULBY, printer." 


\section{“THE \\ FAMOUS HISTORY \\ OF THE \\ VALIANT LONDON \\ APPRENTICE."}

Woodcuts.-Several very rude and worn. On title page, a young man between two houses. In the text we have:- a youngish man in seventeenth century costume: an older one in the same with full bottomed wig : a lady with Fontange headdress, and a fan :- a view of a city, probably intended for London, there being something, which may be old London Bridge: the barque which was on the title page of Soulby's Antonio and Clarissa, but the letter $\mathrm{N}$ has been erased from the main topsail-an interior, two countrymen consulting a man in full bottomed wig, seated at a table; over his head the letter $\mathrm{F}$, and maps of the two hemispheres on the walls, - the figures of Crispin and Crispianus that decorate one of the Whitehaven histories of Thomas Hickathrift, but the picture is reversed. No cut is given of the apprentice vanquishing the two lions.

Imprint.-

"Penrith : printed by A. Soulby."

\section{“THE \\ HISTORY \\ OF \\ RICHARD WHITTINGTON \\ THRICE \\ LORD MAYOR OF LONDON."}

Woodcut.-On title page figure of Crispin from a Newcastle . chap-book, see Ashton's book, p. 223.

Imprint.-

\section{"PENRITH.}

Printed by A. Soulby."

There are several woodblocks; in the text is the portrait of a divine with long hair and skull cap; on p. 9 three women; on p. 12, the same barque that appeared on the title page of Soulby's Antonio and Clarissa, and also on the Valiant London Apprentice, but here it has the letter $\mathrm{U}$ on the topsail. On p. 14, is a circular shield, on which a ship under topsails; supporters two black-a-moors; this must be the arms of some trading company. On p. 16, a representation of God Almighty in the clonds, surrounded by stars. On p. 19, the Lord Mayor's coach. On p. 21 Bartholomew's Hospital, or what is intended for it. 


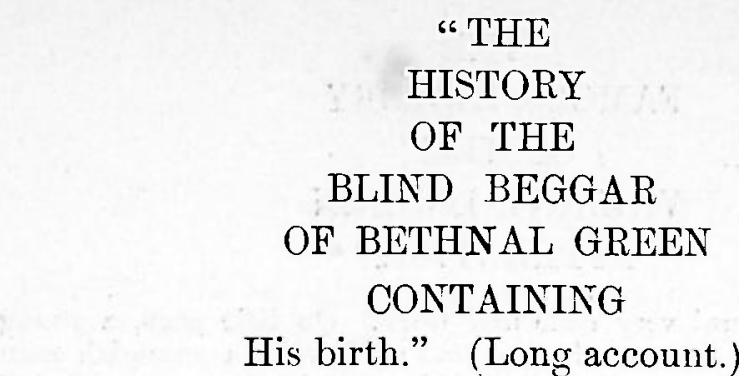

Woodblock.-A conjuror with cards, thimbles and birds.

Imprint.-

“G. ASHBURNER, PRINTER, UIVERSTON."

\section{THE HERMIT OF WARKWORTH. \\ A NORTHUMBERLAND TALE \\ IN THREE PARTS.}

\section{BY DR. THOMAS PERCY, BISHOP OF DROMORE,"}

Woodblock.-A person carrying a cross, ascends a steep and tortuous path up a mountain, while from the skies a hand holds out a crown of glory. A Bewick block (?)

Imprint.-

"PRINTED AND SOLD BY W. FORDYCK.

48, Dean Street, Newcastle.

A variety of Histories and Songs always on hand.

Agent to the Yorkshire Fire and Life Insurance Company.

Annuities and Reversions purchased, and annuities granted."

“ REMARKABLE AND MEMORABLE HISTORY OF SIR ROBT. BEWICK

\section{AND THE \\ LAIRD GRAHAM.}

Giving an account of Laird Graham's meeting with Sir Robert Bewick in the Town of Carlisle and they going to a Tavern, a dispute happened betwixt them, which of their sons was the best man. How Graham rode home in a passion, and caused his Son to fight young Bewick, which proved their deaths. 


\section{ALSO THE BERKSHIRE LADY'S G $\Lambda$ RLAND \\ IN FOUR PARTS."}

Woodblock.-Two Highlanders fighting with broad-swords and targets.

Imprint.-

"Printed and sold by W. and T. Fordyce, Newcastle and Huli; and J. Whinham and Co., 66, Scotch Street, Carlisle."

\section{Class VIII.}

JEST BOOKS.

"THE

HISTORY

OF THE

FROLICKSOME COURTIER

AND THE

JOVIAL TINKER."

Woodcut.-A rude one of St. George and the Dragon. There is a woodcut inside of a man with a bag on his back which is a copy (reversed) of a woodent in The Cries of York published by $\mathrm{T}$. Kendrew, Collier Gate, York. The cuts of his publication afterwards got to Banbury, and appeared in Banbury Cries, Banbury Chapbooks, p. 47.

Imprint.-

"CARLISLE.

Printed by F. JOLLIE, 1796."

$A$ very old collection of coarse practical jokes.

\section{“ THE MERRY AND ENTERTAINLNG JOKES \\ $\mathrm{OF}$}

GEORGE BUCHANAN

WHO

Was servant or Teacher to King JAMES VI. as his private Counsellor, but publicly acted his Fool. The Whole 
compiled in three Numbers for the entertainment of Youth."

In three PARTS.

\section{The Eleventh Edition with Additions.}

Woodcut.-None; but across title page is an ornamental border, which occurs on p. 9 of Ann Dunn's edition of Thomas Hickathrift.

Imprint .-

"Whitehaven; Printed and sold by A. COUTTS."

A well-known and popular but coarse story. This copy has a blue paper cover, and consists of sixteen pages.

\section{“THE PLEASANT AND DELIGHTFUL HISTORY \\ $\mathrm{OF}$}

\section{LAWRENCE LAZY}

\section{CONTAINING}

His Birth and slothful Breeding: and also as he grew to maturity, how he served the School Master and his wife, the Squire's Cook, and Mr. Wheatley the Farmer, which was accounted by the laws of Lubberland, High Treason. And lastly, his Arraignment and Tryal before Sir James Jobson in the Town-Hall of Never-work, concluding with his happy Deliverance from those Treasons which were laid to his charge."

Woodcut.-None on title page, but there are two in the text, which are used in other chap-books by J. Dunn.

Imprint.-

“WHITEHAVEN.

Printed for and sold.by J. Dunn." 
Crass IX.

NATURAL HISTORY.

“ THE SURPRISING

HISTORY

OF THE

LEVIATHAN

OR

RITER HORSE

Found in the Rivers of Africa.

Shewing the

Wonderful properties of that Amphibious Animal, which lives on the land or in the water, whose teeth strike fire like a flint stone. As also the dangerous manner of catching him."

Woodblock.-A horse, or rather a zebra.

Imprint.-

"FALKIRK.

PRINTED BY T. JOHNSTON, 1801." 